\title{
ANDRIY MYKHALEYKO
}

\section{The New Independent Orthodox Church in Ukraine}

\begin{abstract}
In January 2019, the Ukrainian Orthodoxy received what is known as the tomos from the Ecumenical Patriarchate of Constantinople, which established the independent Orthodox Church in Ukraine. The granting of autocephaly to the Orthodox Christians of Ukraine caused a deep crisis in the Orthodoxy and a conflict between Constantinople and Moscow. The Russian Orthodox Church (ROC) condemned the Ecumenical Patriarch's action and accused the Patriarchate of Constantinople of encroaching on the 'canonical territory' of the ROC. The author examines the foundations of this formation of a new Orthodox Church, the religious and political factors influencing the process of its establishment, and the reaction of the Russian Orthodox Church leadership and Russian politicians. He also reflects on the consequences for relations within Orthodoxy, for ecumenical dialogue, and for contacts between Ukraine and Russia.
\end{abstract}

Andriy Mykhaleyko is a priest of the Ukrainian Greek Catholic Church, and a private lecturer at the Catholic University of Eichstätt-Ingolstadt.

\section{The Tomos - Word of the Year in Ukraine}

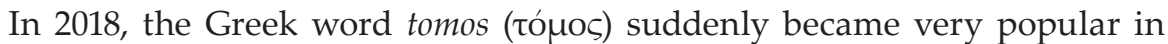
the Ukrainian media. Within eight months it was voted 'word of the year'. Tomos - a term used to describe an ecclesiastic decree in the Orthodox tradition, including the conferment of autocephaly-was, until recently, known only to a small circle of specialists familiar with ecclesiastic terminology. In April 2018, the public heard the term for the first time after the then Ukrainian president, Petro Poroshenko, appealed to the Patriarch of Constantinople to grant autocephaly to Ukrainian Orthodoxy. In the following months, the tomos came to symbolize these efforts to achieve independence for the Ukrainian church, and thereby political independence from Russia. In December 2018, Ukrainians declared the unification of the churches and the conferment of the tomos the most important political event of the year. Earlier the same year, the Ukrainian Ministry of Education made the decision to include the event in the textbooks for the eleventh-grade school subject 'History of Independent Ukraine'. 
The endeavour to achieve ecclesiastical autocephaly or independence within Orthodoxy is, in and of itself, an internal church affair. However, as in previous cases of individual national Orthodox churches being granted independence, and also in light of the current situation in Ukraine, as well as its relationship to Russia, this becomes a highly explosive political issue that should not be underestimated. In the following, I discuss the influence of the conferment of autocephaly within the Ukrainian Orthodoxy, as well as on World Orthodoxy, and also how it has affected Ukrainian-Russian relations. In the first part of the paper, I examine the historical background of the conferment of Orthodox autocephaly. My intention is to explore how it came to be that a new, independent church was created in Ukraine, as well as to analyse the tomos with the aim of enhancing our understanding of the current situation. In the second part, I then attempt to outline the consequences for universal Orthodoxy, as well as for ecumenical dialogue. In the third part, I strive to determine the possible impact on the political situation as well as on Ukrainian-Russian relations.

\section{The Ecclesiastic Historical Background of the Tomos Conferment}

The analysis of the establishment of a new, independent, Orthodox church in Ukraine reveals an interdependence of various factors common to the whole of Orthodoxy. The Orthodox Church is a community of autocephalous and self-governing churches, whose sole bond is a mutual faith and being in full communion with each other. The concept of autocephaly is, thus, an inherent part of Orthodox ecclesiology. However, the question of how a new autocephalous church can be established remains highly controversial within Orthodoxy. Over the course of history, the old Patriarchates of Constantinople, Alexandria, Antioch, and Jerusalem had become quite important, evolving and establishing themselves at the first ecumenical councils. That said, the attainment of independence by the Orthodox churches in the modern era, particularly from the $19^{\text {th }}$ century to the present day, resulted in unprecedented internal Orthodox tensions. The close link between religion or denomination and a specific ethnicity or state, within whose borders an Orthodox Church exists, was and remains a characteristic of such new formations. The autocephalic aspirations often came to the fore in the context of political developments, notably the emergence of new nation-states. In accordance with the concept of 'in an independent state - an independent church', the respective churches demanded independence from their 'Mother Churches', or, unceremoniously, declared themselves autocephalous. The 'Mother Churches', however, did not accept their ecclesiastical scope of influence being reduced, or the sudden disobedience from structures that had previously been subordinate 
to them. For example, the Moscow fraction of the Kiev Orthodox Metropolitanate declared itself autocephalous in 1448, but was not recognized by Constantinople until 1589. ${ }^{1}$ The schism between Constantinople and the Serbian Orthodox Church lasted 38 years (1882-1920); between Constantinople and the Greek Orthodox Church, 17 years (1833-1850); between Constantinople and the Bulgarian Orthodox Church, 73 years (1872-1945); between Moscow and the Georgian Orthodox Church, 26 years (1917-1943); between Moscow and the Polish Orthodox Church, 24 years (1924-1948); and the rift between the Serbian Orthodox Church and the Macedonian Orthodox Church, which developed in 1967, remains unresolved to this day.

The history of the new Orthodox Church in Ukraine also features some of these fundamental developments, characteristic of Orthodoxy. The Orthodox Metropolitanate of Kiev was subordinated to the Patriarchate of Moscow towards the end of the $17^{\text {th }}$ century and remained unchallenged until the collapse of the Tsarist Empire at the end of the First World War. In parallel with the efforts to establish an independent Ukrainian state, attempts were also made, from 1917 to 1921, to proclaim the Ukrainian Autocephalous Orthodox Church (UAOC). ${ }^{2}$ As a result, a part of the Orthodox Church in Ukraine divorced itself from the ROC and unilaterally proclaimed autocephaly. However, neither the political nor the ecclesiastical aspirations were successful. A few years after the proclamation of autonomy, the autocephalous church was dissolved by the Soviets. A second, also unsuccessful attempt to declare autocephaly took place during the Second World War. Only after the fall of the Soviet Union was it possible for the two independent churches to permanently establish themselves. In 1990, the UAOC was initially restored, mainly in western Ukraine. Around the same time (in 1992), a part of the Ukrainian Orthodox Church, the Moscow Patriarchate (UOC MP), formed the Ukrainian Orthodox Church of the Kiev Patriarchate (UOC KP). The aim was for the UOC KP to distinguish itself from the dominant church of the Moscow Patriarchate. Both churches were denied recognition by World Orthodoxy and were considered non-canonical until 2018. According to Orthodoxy, a church is canonical when it stands in 'unity of faith as well as in prayer and canon-

\footnotetext{
${ }^{1}$ Wolfram von Scheliha, Russland und die orthodoxe Universalkirche in der Patriarchatsperiode, 1589-1721, Wiesbaden 2004, 27-63.

${ }^{2}$ On the attempts to establish an independent church in the history of Ukrainian Orthodoxy cf. Serhii Plokhy, Kyiv vs Moscow. The Autocephalous Movement in Independent Ukraine, in: Serhii Plokhy / Frank E. Sysyn, eds, Religion and Nation in Modern Ukraine, Edmonton et al. 2003, 136-145; Alfons Brüning, Orthodox Autocephaly in Ukraine. The Historical Dimension, in: Andrii Krawchuk/Thomas Bremer, eds, Churches in the Ukrainian Crisis, London 2016, 79-101; Martin-Paul Buchholz, Zwischen Spaltungen und Einheitsbestrebungen. Die ukrainische Kirchengeschichte seit der Unabhängigkeit, Una Sancta 74, no. 2 (2019), 91-103.
} 
ical communion with the other national Orthodox churches'. ${ }^{3}$ In being noncanonical, the two Ukrainian churches were neither in communion with nor did they have an official relation to the other canonical Orthodox churches.

Despite several attempts by the representatives of both non-canonical churches, as well as the Ukrainian political leadership, neither the Patriarchate of Constantinople nor the Moscow Patriarchate could be convinced to change the canonical status of either unrecognized churches. This situation prevailed for 27 years. According to Moscow and Constantinople, the only possible way of restoring their unrecognized status to a canonical status was for them to go back to being a canonically recognized church-the UOC MP. However, this option was, for ecclesiastical and national political reasons, unacceptable for either church. Even though the UOC MP had 'broad autonomy', it nevertheless had a very close relationship with the ROC. For the two churches, such a unification would mean returning to a position of subservience to the Patriarch of Moscow.

In the spring of 2018, however, things began to change. On 19 April, the Ukrainian president, after having met with the Ecumenical Patriarch Bartholomew on 9 April, turned to parliament and presented a resolution demanding that his request to the head of the 'Mother Church', the Patriarch of Constantinople, to grant the tomos, be supported. He referred to a conversation with the Patriarch at Easter and emphasized that the conferment of autocephaly would restore historical justice to Ukrainian Orthodoxy. With the support of the two non-canonical churches and the parliament, and despite objections from the opposition, which has many supporters of the UOC MP among its numbers, the process to grant autocephaly was initiated. Since then, this religious issue has been a subject of public debate.

The Ukrainian government's request was addressed to Constantinople in its twofold function. First as the 'Mother Church' of the Kiev Metropolis-from which the Slavs from the East accepted Christianity in the $10^{\text {th }}$ century, and on which, for 700 years, a large part of the Kiev Metropolitanate was canonically dependent. And second as the Centre of World Orthodoxy. The Patriarchate of Constantinople's claim to be the 'Mother Church' for Ukrainian Orthodoxy today, however, has been seriously challenged by the ROC, which, in fact, has considered itself as occupying this role ever since the Kiev Metropolitanate was joined to the Patriarchate of Moscow in 1686. The incorporation of the

${ }^{3}$ Hans-Dieter Döpmann, Kirchliche Identität und kanonisches Territorium, in: Thomas Bremer, ed, Religion und Nation. Die Situation der Kirchen in der Ukraine, Wiesbaden 2003, 53-66, 53.

${ }^{4}$ Cf. the Ukrainian president's website, Zvernennia Prezydenta Ukraïny do Vselens'koho Patriarkha Varfolomiia, 17 April 2018, https://www.president.gov.ua/administration/ zvernennya-prezidenta-ukrayini-do-vselenskogo-patriarha-varf-438. All internet references were accessed on 15 December 2019. 
Metropolis into the ROC-which, after the 1667 Peace Treaty of Andrusovo between Poland-Lithuania and Moscow, followed the incorporation of large parts of today's Ukraine into Moscow's domain-is contested by historians to this day. Those who support Ukrainian autocephaly claim that the submission of the Kiev Metropolitanate to the Patriarch of Moscow was not canonical. ${ }^{5}$ During the preparations for the conferment of autocephaly, in September 2018, the Patriarch of Constantinople even published a study entitled 'Ecumenical Patriarchate, the Ecumenical Throne, and the Church of Ukraine. The Documents Speak', in order to justify his own decision. ${ }^{6}$ Based on the documents used in the publication and his interpretation, he claims that the action of 1686 was only of 'temporal' character and relied on the principle of oikonomia. Aside from this, the event of 1686 had nothing to do with a complete submission of the Kiev Metropolitanate to the Patriarchate of Moscow. On 15 October 2018, the ROC rejected the Patriarchate of Constantinople's interpretation as unlawful, referring to the year 1686 as the year of the unification of the 'Russian Church'.7 Studies that take a more moderate stance point out that the issue has not yet been resolved and that further research needs to consider all terminological, ecclesiastical, and historical-contextual particularities. ${ }^{8}$

The major divergences in the interpretation of the 1686 event have far-reaching consequences when it comes to answering the fundamental question of which Orthodox church is currently allowed to confer autocephaly. As already mentioned above, the Orthodoxy has no uniformly recognized procedure for this. By claiming its primacy within World Orthodoxy, the Patriarchate of Constantinople claims the right to confer autocephaly. The Moscow Patriarchate, on the other hand, asserts that this issue concerns universal Orthodoxy and should, therefore, be agreed upon by all autocephalous Orthodox churches. ${ }^{9}$ In 2016, Orthodoxy missed its chance of making a joint and binding deci-

\footnotetext{
${ }^{5}$ Brüning, Orthodox Autocephaly in Ukraine, 93-94.

${ }^{6}$ Cf. English version, Ecumenical Patriarchate, The Ecumenical Throne and the Church of Ukraine. The Documents Speak, 18 September 2018, https://www.patriarchate.org/ theological-and-other-studies/-/asset_publisher/GovONi6kIiut/content/o-oikoumenikosthronos-kai-e-ekklesia-tes-oukranias-omiloun-ta-keimena?_101_INSTANCE_GovONi6kIiut_ languageId=en_US.

7 The Russian Orthodox Church, Department of External Church Relations, Statement by the Holy Synod of the Russian Orthodox Church Concerning the Encroachment of the Patriarchate of Constantinople on the Canonical Territory of the Russian Church, 15 October 2018, https://mospat.ru/en/2018/10/15/news165263/; or Osteuropa 68, no. 8-9 (2018), 109-114.

${ }^{8}$ For example, Vera G. Chentsova, Sinodalnoe reshenie 1686 o Kievskoŭ mitropolii, Drevniaia Rus'. Voprosy medievistiki 68, no. 2 (2017), 89-110.

${ }^{9}$ On the differences between Moscow and Constantinople concerning the conferment of autocephaly cf. Paul Brusanowski, Autocephaly in Ukraine. The Canonical Dimension, in: Krawchuk / Bremer, eds, Churches in the Ukrainian Crisis, 47-77. On the general Orthodox problem concerning autocephaly cf. Athanasios Vletsis, Orthodoxie 'reloaded' oder das
} 
sion on this matter. Because there was no prior consensus regarding this issue and no joint document could be agreed upon, it was not raised at the 'Holy and Great Council of the Orthodox Church' in Crete, where not all Orthodox churches were in attendance.

The lack of clarity concerning this question was grist to the mill of the proponents of Ukrainian autocephaly. This does not mean, however, that the opponents of autonomy for the Ukrainian church merely stood by and observed. It was predictable that, after receiving initial positive signals regarding Ukrainian autocephaly from Constantinople, the harshest reaction would come from the Moscow Patriarchate. The Patriarchate of Moscow hoped to sway the Ecumenical Patriarch's point of view by the end of summer 2018. On 31 August of that year, the Russian Orthodox Patriarch Cyril even visited Patriarch Bartholomew at Phanar, the district of Istanbul where the Patriarchate of Constantinople has its seat, to persuade him to change his mind. The visit, however, did not bring about a change of heart and each side maintained their point of view on the issue. ${ }^{10}$

The decisions in the weeks following this meeting reveal that there was no turning back. Just a few days after Cyril's visit, on 7 September, Bartholomew sent two Exarchs of the Patriarchate, Archbishop Daniel (Zelinsky) of Pamphilon and Hilarion (Rudyk) of Edmonton (both of Ukrainian descent) to Ukraine in order to prepare for autocephaly. In a next step, the Patriarchate of Constantinople, at a synod of bishops on 11 October, declared both non-canonical churches in Ukraine to be canonical and rescinded the 1686 decision to integrate the Kiev Metropolitanate into the Moscow Patriarchate, simply by describing it as out-of-date. ${ }^{11}$ In return, on 18 October 2018, the Ukrainian Parliament handed over the Kiev St. Andrew's Church to the Patriarchate of Constantinople for them to use. ${ }^{12}$

The church assembly in Kiev, which took place on 15 December and to which the Ecumenical Patriarch Bartholomew had invited bishops from all three Ukrainian Orthodox churches, was eagerly anticipated. The Council for the Unification took place in what for the Eastern Slavs is the most important

Ende der Orthodoxie? Der Ukraine-Konflikt als Chance einer neuen 'Formatierung' in der Orthodoxen Kirche, Una Sancta 74, no. 2 (2019), 151-168.

${ }^{10}$ Keine Einigung im ukrainischen Kirchenstreit. Wem gehört die Ukraine?, 31 August 2018, https:/www.domradio.de/themen/\%C3\%B6kumene/2018-08-31/keine-einigung-imukrainischen-kirchenstreit.

${ }^{11}$ Ecumenical Patriarchate, Announcement, 11 October 2018, https://www.patriarchate.org/ announcements/-/asset_publisher/MF6geT6kmaDE/content/communiq-1?_101_INSTANCE_ MF6geT6kmaDE_languageId=en_US.

12 Parlament übergibt Andreaskirche in Kyjiw an Patriarchat Konstantinopel, ukrinform, 18 October 2018, https://www.ukrinform.de/rubric-society/2561095-parlament-ubergibtandreaskirche-in-kyjiw-an-patriarchat-konstantinopel.html. 
church of Kiev, Saint Sophia, where in October 1921 the attempt to declare autocephaly had failed. Until the very day of the council it was unclear how many bishops from the UOC MP would take part. Behind the scenes there was talk of about ten hierarchs having announced their readiness to attend. In the end, only two out of the more than 80 bishops of the UOC MP participated in the council. This diminished the historical significance of the assembly. Nonetheless, the head of the new church was elected on 15 December. On 6 January 2019, during a festive Liturgy, Patriarch Bartholomew conferred the long-awaited tomos at Phanar, declaring the new autocephalous church and welcoming it into the community of Orthodox churches.

\section{The Main Topics of the Tomos}

What focal issues does the tomos raise for the new Orthodox church in Ukraine? The document deserves a more thorough analysis than this study can provide, but for the purposes of this article, I will cover just a few of the most important details. Firstly, the tomos declares the new church as independent and self-governing. ${ }^{13}$ According to the tomos, the Orthodox Church of Ukraine is to regulate its affairs through its own synod and without external interference. The document does not limit itself to purely formal explanations, but includes important guidelines on structure, on the relationship of the new church to the Ecumenical Patriarchate, the other Orthodox churches, and the state. If we take a closer look at the tomos, it is apparent that many of its provisions are consistent with the statutes of this church. ${ }^{14}$ However, due to the demands of the Ecumenical Patriarchate, the Ukrainian side had to make many compromises. Here I will outline just three examples.

Firstly, regarding the definition of the church, the document names the new church the 'Orthodox Church of Ukraine' or, more specifically, the 'Orthodox Church in Ukraine' (OCU) rather than the Ukrainian Orthodox Church, which is the title that would correspond with other Orthodox churches. Most Orthodox churches have a nation with which the church identifies itself. It can be assumed that giving the new church this title is a signal against phyletism, in other words against an 'overemphasis of the race or the nation towards the

${ }^{13}$ Ecumenical Patriarchate, Patriarchal and Synodal Tomos for the Bestowal of the Ecclesiastical Status of Autocephaly to the Orthodox Church in Ukraine, 14 January 2019, https:// www.patriarchate.org/-/patriarchikos-kai-synodikos-tomos-choregeseos-autokephalouekklesiastikou-kathestotos-eis-ten-en-oukraniai-orthodoxon-ekklesian.

14 For some remarks on the statutes of the OCU cf. Kyryll Hovorun, Markery zmin. Komentari do Stytutu Pravoslavnoï Tserkvy Ukraïny, LB.ua, 3 January 2019, https://lb.ua/ society/2019/01/03/416364_markeri_zmin_komentari_statutu.html. 
church'. ${ }^{15}$ Phyletism is a tendency to define an Orthodox autocephalous church through its close attachment to the respective nation. It evolved in the $19^{\text {th }}$ century under the Orthodox churches, primarily in Southeastern Europe, in parallel with the formation of what were known as 'national Orthodox churches'. To this day, it presents a serious problem in Orthodoxy, due to the fact that it harbours an inherent danger of nationalism. As early as the $19^{\text {th }}$ century, Constantinople accused the churches that had separated themselves and that had organized themselves according to the principle of nationalities of phyletism, which it viewed as being in contradiction to the Spirit of the Gospel. ${ }^{16}$

Secondly, in its structure, the new church remains a metropolitan church. Even though the Ukrainian side desired the status of Patriarchate, it is, according to the tomos, led by a metropolitan, who goes by the title of 'Metropolitan of Kiev and All Ukraine'. This title cannot be changed without the express approval of Constantinople. The head of the church received the Holy Myron from Constantinople, as a sign of spiritual unity with the Ecumenical Patriarchate. A certain dependence on Constantinople can also be seen in the field of dogmatic theology. For the clarification of more important questions of ecclesiastical, dogmatic, and canonical character, the Metropolitan of Kiev has to turn to the Ecumenical Seat in the name of the Holy Synod of his Church. ${ }^{17}$

Thirdly, the OCU is not allowed to deploy any bishops or found any parishes outside of Ukraine as the document restricts the jurisdiction of the church solely to the territory of the Ukrainian state. The structures and parishes that already exist are to immediately subordinate themselves to the Ecumenical Seat, which lays claim to the canonical authorities in every diaspora. This demand corresponds with claims made by Constantinople, which, according to Canon 28 of the Fourth Ecumenical Council of Chalcedon (451), has jurisdiction over the Orthodox Christians in the diaspora:

'And the one hundred and fifty most religious Bishops, actuated by the same consideration, gave equal privileges to the most holy throne of New Rome, justly judging that the city which is honoured with the Sovereignty and the Senate, and enjoys equal privileges with the old imperial Rome, should in ecclesiastical matters also be magnified as she is, and rank next after her; so that, in the Pontic,

${ }_{15}$ Theodor Nikolaou, Die Orthodoxe Kirche im Spannungsfeld von Kultur, Nation und Religion, St. Ottilien 2005, 84.

16 An example of this is the Bulgarian Orthodox Church, which was declared schismatic by Constantinople at the 1872 Synod and which was excluded from church fellowship. Martin Illert, Die Bulgarische Orthodoxe Kirche und die 'Heilige und Große Synode', Religion und Gesellschaft in Ost und West 11 (2016), 14-16, 15; Jürgen Henkel, Dumitru Stăniloae. Leben. Werk. Theologie, Freiburg et al. 2017, 365.

${ }^{17}$ Ecumenical Patriarchate, Patriarchal and Synodal Tomos for the Bestowal of the Ecclesiastical Status of Autocephaly to the Orthodox Church in Ukraine, 14 January 2019, https:// www.patriarchate.org/-/patriarchikos-kai-synodikos-tomos-choregeseos-autokephalouekklesiastikou-kathestotos-eis-ten-en-oukraniai-orthodoxon-ekklesian. 
the Asian, and the Thracian dioceses, the metropolitans only and such bishops also of the Dioceses aforesaid as are among the barbarians, should be ordained by the aforesaid most holy throne of the most holy Church of Constantinople. ${ }^{18}$

In 2017, this designation affected about 44 parishes from the European continent that belonged to the former Ukrainian Orthodox Church of the Kiev Patriarchate: two parishes in the Netherlands, eight in Italy, six in France, five in Sweden, six in Germany, three in Spain, five in Portugal, and one each in Hungary, the Czech Republic, Great Britain, Lithuania, Finland, Austria, Slovenia, Greece, and Switzerland. ${ }^{19}$ In addition to this, there were ten parishes in Moldavia and about fifteen in the United States and Canada. Since 6 January 2019, all of them are said to belong to the jurisdiction of the Ecumenical Patriarchate. It seems that there is a link between this provision in the tomos and the November 2018 decision of the Patriarchate of Constantinople to dissolve the Orthodox Exarchate of Paris and to integrate its parishes into the structures of the Metropolitanates of the Patriarchate of Constantinople in Western Europe. It is not yet clear how Constantinople's attempt to unify different structures in the diaspora will be put into practice. In any case, the abolition of the exarchate triggered a heated debate and met with disapproval from a substantial part of its clergy. It remains to be seen whether the Ukrainian Orthodox communities in Western Europe will give in to the provisions of the tomos.

\section{The Consequences for World Orthodoxy and Ecumenical Dialogue}

In 1942, the German historian Eduard Winter published the book 'Byzantium and Rome in the Fight for Ukraine 955-1939'. ${ }^{20}$ He explored how, over the course of history, since the Baptism of the Kievan Rus, both important Christian centres-Rome and Constantinople-attempted to influence Ukraine. The current controversies, at the intra-Orthodox level, could be described as a struggle between Constantinople and Moscow, the second and the third Rome, over the Ukrainian Orthodoxy. Is World Orthodoxy splintering over the Ukraine issue? This question seems wholly justified. Although the consequences are difficult to predict, there is every reason to believe that the internal Orthodox conflict could last for years.

${ }^{18}$ Philip Schaff, The Seven Ecumenical Councils, Nicene and Post-Nicene Fathers 2, vol. 14, Canon 28, available online in the Christian Classical Ethereal Library, http://www.ccel.org/ ccel/schaff/npnf214.xi.xviii.xxviii.html.

19 'Ieparkhiï UPTs KP za kordonom. Tse ostrovy viry ta nadiï', - Rivenskyı̆ arkhiiepyskop Ilarion, Religija v Ukraïni, 10 April 2018, https://www.religion.in.ua/zmi/ukrainian_zmi/ 39437-yeparxiyi-upc-kp-za-kordonom-ce-ostrovi-viri-ta-nadiyi-rivnenskij-arxiyepiskopilarion.html.

${ }^{20}$ Eduard Winter, Byzanz und Rom im Kampf um die Ukraine (955-1939), Leipzig 1942. 
After the fall of the Soviet Union, tensions, even a short-lived schism, already existed between Constantinople and Moscow. In 1996, the main issue was the jurisdiction over the Orthodox Church in Estonia. At that time, in Estonia, two coexisting Orthodox structures had been created through the separation of the country's Orthodox church. Part of the Orthodox community became subordinate to the Patriarchate of Constantinople, and the other part kept its autonomous status in the canonical relationship with Moscow. While in the case of Estonia the number of members is quite small (in total about 177,000), when it comes to Ukraine, for the ROC, it is not merely a matter of reducing their communities. The ROC not only enjoys a high reputation within Orthodoxy but is currently considered one of the most influential churches in World Orthodoxy. The loss of ecclesiastical influence on the Ukrainian religious landscape through the loss of its communities is thus tantamount to a bitter defeat against its rival in Constantinople and a setback for its supremacy in World Orthodoxy.

It is not surprising that the announcement of Constantinople's plan to confer autocephaly was met with much criticism in the Moscow Patriarchate. The situation came to a head after it became clear that Constantinople was unwilling to give in and reverse its decision. The Patriarchate of Moscow considered the actions of the Patriarchate of Constantinople to be an encroachment on the ROC's area of responsibility. In a press release on 8 September 2018, one day after Constantinople called for the exarch to be deployed to Ukraine, Metropolitan Hilarion (Alfeev), chairman of the Department of External Church Relations of the Moscow Patriarchate, warned of the serious consequences this would have for the Orthodoxy: 'The Patriarchate of Constantinople is now on the warpath. This is not only a war against the Russian Church and the Ukrainian Orthodox people. It is essentially a war against the unity of the entire World Orthodoxy.'21 He placed sole responsibility for the seriousness of the situation within Orthodoxy on the Patriarch of Constantinople and threatened him with the Last Judgment: 'I believe that Patriarch Bartholomew will personally bear the responsibility before the court of God and in the court of history.'22

After exhausting all means of ecclesiastical diplomacy, the Holy Synod of the ROC decided to suspend Eucharistic Communion with Constantinople at its meeting in Minsk on 15 October 2018. ${ }^{23}$ Since then, the name of the Patriarch of Constantinople has no longer been commemorated in the Divine Liturgy by

\footnotetext{
${ }^{21}$ Regula Zwahlen, Ukrainischer Kirchenstreit droht zu eskalieren, Religion und Gesellschaft in Ost und West 10 (2018), 3-4.

${ }^{22}$ Zwahlen, Ukrainischer Kirchenstreit droht zu eskalieren, 4.

${ }^{23}$ The Russian Orthodox Church, Statement by the Holy Synod of the Russian Orthodox Church; Gunther Wenz, Bruderzwist im Haus der Orthodoxie. Zum aktuellen Streit des Moskauer und Konstantinopeler Patriarchats, Una Sancta 74, no. 2 (2019), 82-90.
} 
his counterpart in Moscow. Moreover, it has also been said that bishops and priests of the ROC are no longer allowed to celebrate church services together with the clergy of the Patriarchate of Constantinople. The same applies to the Russian Orthodox lay people. They are no longer allowed to receive any sacraments in the churches of the Ecumenical Patriarchate. ${ }^{24}$

The Patriarchate of Moscow also fiercely criticized the tomos conferment. In his speech on 31 January 2019, Patriarch Cyril (Gundjaev) accused the church of Constantinople of 'illegally encroaching on the territory of the Ukrainian Orthodox Church'. ${ }^{25}$ This allegation is based on article I.3 of the 2013 ROC statute, according to which Ukraine (as well as some other successor states of the USSR) belong to the canonical territory of the Moscow Patriarchate:

'The jurisdiction of the Russian Orthodox Church extends to persons of the Orthodox faith, who live in the canonical territory of the Russian Orthodox Church: in the Russian Federation, in Ukraine, in the Republic of Belarus, in the Republic of Moldova, in the Republic of Azerbaijan, in the Republic of Kazakhstan, in Turkmenistan, in the Republic of Uzbekistan, in the Republic of Estonia, in Japan, as well as those who, of their own free will, are Orthodox members and living in other states. ${ }^{26}$

The term 'canonical territory' used here remains controversial both in the context of relations between the Roman Catholic and the Russian Orthodox Church and within Orthodoxy. It is also rather difficult to define as it can refer to a variety of different aspects, from an ecclesiological, geographical, and cultural entity to the territorial or canonical jurisdiction of a church as an expression of its local community, or the pastoral theological care of the faithful in a particular territory. ${ }^{27}$ In the current dispute between Moscow and Constantinople over Ukraine, two views are irreconcilable: the ROC claims exclusive jurisdiction of the territory of Ukraine, and the Patriarchate of Constantinople contests and challenges this claim. In addition to this, as of late, the Ukrainian side, which includes both Orthodox and Greek Catholic theologians and historians, has increasingly tried to claim the existence of

\footnotetext{
${ }^{24}$ The Russian Orthodox Church, Statement by the Holy Synod of the Russian Orthodox Church; Dagmar Heller, 'Wenn ein Glied leidet, ...' Die Auswirkung der inner-orthodoxen Spannungen auf die Ökumene, Una Sancta 74, no. 2 (2019), 140-150, 140-144.

${ }^{25}$ Cf. the website of the Russian Orthodox Church, Vystuplenie Sviateřshego Patriarkha Kirilla na torzhestvennom akte, posviashchennom 10-letiiu Pomesnogo Sobora i intronozatsii Iego Sviateřshestva, 31 January 2019, http://www.patriarchia.ru/db/text/5364415.html.

${ }^{26}$ Anargyros Anapliotis, ed, Die Statuten der Russischen Orthodoxen Kirche, München 2015, 79 .

${ }^{27}$ Döpmann, Kirchliche Identität und kanonisches Territorium, 53-66; Jennifer Wasmuth, Russian Orthodoxy between State and Nation, in: Andrii Krawchuk/Thomas Bremer, eds, Eastern Orthodox Encounters of Identity and Otherness. Values, Self-Reflection, Dialogue, New York/NY 2014, 17-27, 21-23.
} 
a particular type of Christianity that developed on Ukrainian territory, and which differed greatly from Russian or Belarusian Christianity. This type of Christianity is called 'Kievan Christianity' or the 'Kievan tradition'. Its essential characteristics include a unique form of religious culture as well as specific values that embrace both sacred and profane spaces and are characterized by an openness to Western religious and political cultures. ${ }^{28}$ Both the Orthodox and the Greek Catholic Church are seen as bearers of this particular type of Christianity. Nevertheless, an acceptable definition of the term 'Kievan Christianity' remains elusive. To make things even more complicated, the attempt to scientifically conceptualize the idea of 'Kievan Christianity' has included integrating the UOC MP into this project. This is difficult to ignore. Yet, in the current conflict this church is seen more as the bearer of the ideas of the 'Russian world' and not so much as the heir of a special kind of Ukrainian Christianity. Moreover, due to the current political context it is extremely difficult to keep the concept of a 'Kievan Christianity' exclusively within the framework of scholarly discourse. Instead, it is used as an ideological argument to justify not only a religious, but also a political, national, and cultural otherness of Ukrainians when it comes to Russia.

Taking these disparities into consideration, Moscow's reaction to Constantinople's actions is understandable. No church would silently accept their positions on a certain territory being weakened or even endangered. On the other hand, if one looks at the developments of the church in Ukraine since 1990, it can also be said that the church itself is, to some extent, complicit in the escalation of the situation in Ukraine. Perhaps, over the last two decades, the Moscow Patriarchate made the mistake of failing to propose solutions to permanently settle the schism in Ukraine that would have been acceptable to the conflicting parties (other than the return to the canonical UOC MP). If it had, it might have gained more leeway to help shape the future of Orthodoxy in Ukraine. ${ }^{29}$

\footnotetext{
${ }^{28}$ A few years ago, at the Ukrainian Catholic University, an attempt was made to scientifically develop this idea within the framework of the project 'Kyivan Christianity'. Cf. Ihor Skochylias' speech on the university's website, Ihor Skochylias, Pro sofiünist' iak ekleziǔnu mriiu ta ikonu khrystyianstva, 5 April 2019, http://kyiv-christ.ucu.edu.ua/igor-skochylyaspro-sofijnist-yak-eklezijnu-mriyu-ta-ikonu-hrystyyanstva-kyyiv-5-kvitnya-2019/; Ihor Skoczylas, Slavia Unita. The Cultural and Religious Model of the Archdiocese of Kiev in the Seventeenth and Eighteenth Centuries, in: Jerzy Kłoczowski/Hubert Łaszkiewicz, eds, East-Central Europe in European History. Themes and Debates, Lublin 2009, 243-254. On the prehistory and background of the building of the Greek Catholic Orthodox 'The Kievan Church Study Group' cf. Serge Keleher, The Kievan Church Study Group. 'Impossible Dialogue'?, in: Bert Groen/Wil van den Bercken, eds, Four Hundred Years. Union of Brest, 1596-1996. A Critical Re-evaluation, Leuven 1998, 183-192.

${ }^{29}$ Regina Elsner/Nadezhda Beljakova, Geopolitik, Macht und kirchliche Identität. Der Konflikt um die orthodoxe Kirche in der Ukraine, Ukraine-Analysen 211 (2019), 5-8, 6.
} 
The longer the conflict lasts, the more inevitable it seems that, sooner or later, the other Orthodox churches will be forced to position themselves. ${ }^{30}$ In all likelihood, Orthodoxy will be fragmented into three factions. Firstly, the proponents of the Patriarchate of Constantinople, who approve of Bartholomew's decisions and, thus, support the creation of a new church in Ukraine. Secondly, those Orthodox churches that agree with the ROC's rejection of such a development. Thirdly, those who endeavour to find a middle ground between the two factions and maintain contact to both. Six months after the tomos conferment, an initial assessment showed that the Orthodox churches were not likely or inclined to recognize the OCU prematurely. The primary reasons for their hesitation include their regard for the Moscow Patriarchate's position, but also the controversial issue of the validity of the episcopal ordinations in the OCU as well as the sacraments that had previously been administered. This is all the more pertinent since one of the key figures of this church, 'Honorary Patriarch' Philaret (Denysenko), was already excommunicated by the ROC back in 1997 and considered 'anathema'. The consecrations and the sacraments that he administered to many Orthodox churches would, therefore, lack validity. By contrast, some Orthodox churches (the Albanian Orthodox Church, for instance) are calling for a pan-Orthodox assembly (synaxis) to clarify the crisis in Orthodoxy. ${ }^{31}$

The division within Orthodoxy has already revealed its impact on interchurch relations in Ukraine and international ecumenism. This is currently manifesting itself in the tension between two churches competing for leadership in Ukrainian Orthodoxy, the OCU and the UOC MP. Surprisingly, a new level of conflict has developed between the OCU and the Ukrainian Greek Catholic Church (UGCC). On the one hand, the UGCC did not interfere during the preparatory phase for the establishment of the new church. On the other hand, it welcomed the autocephalic aspirations that would serve to strengthen Ukrainian Orthodoxy. Sociological polls in 2018 showed an interesting tendency toward increasing support for an independent Orthodox church in Ukraine not only among the Orthodox but also, for national political reasons, among the Greek Catholic Christians. According to a survey, published by the sociological Rating Group Ukraine on 17 October 2018, 64 percent of the Greek Catholic Christians who were interviewed felt very positive about the idea of establishing one local church (Ukr. Помісної) in Ukraine. Interestingly,

\footnotetext{
30 Alfons Brüning, 'Einfach orthodox?' Ukraine. Die Gläubigen und die Gesellschaft, Osteuropa 68, no. 8-9 (2018), 119-138.

31 Albanien. Orthodoxie übt Kritik an Bartholomaios und Kyrill, Vatican News, 17 March 2019, https://www.vaticannews.va/de/welt/news/2019-03/orthodox-ukraine-moskau-albaniensynaxis-schisma-autokephal.html.
} 
among the members of the UOC KP, support for this idea was 56 percent. ${ }^{32}$ In the first weeks after the creation of the new Orthodox Church, tensions between the UGCC and the OCU persisted, despite the unanimity among the members of both churches. The cause of these initial tensions was the desire of the head of the UGCC, the Major Archbishop Sviatoslav (Shevchuk), to celebrate a liturgy on 7 April 2019, the Feast of the Annunciation of Mary, according to the old Julian calendar. This should have taken place in the main sanctuary of Ukraine, the Church of Saint Sophia, and thus had a great symbolic significance. To mark the occasion, he had also planned a Greek Catholic pilgrimage to Kiev.

Shortly before this event, in January 2019, Major Archbishop Shevchuk had published a pastoral letter 'Our Saint Sophia' concerning the historical and contemporary significance of this sanctuary for the entire Ukrainian people. ${ }^{33}$ To all appearances, by writing the pastoral letter, he intended to make clear that the UGCC was against any claim that only the OCU may use this historically significant church. Even though the Holy Sophia church has been a museum for many decades, the OCU, with the permission of the responsible state officials, not only held the Unification Council in this church on 15 December 2018, but also celebrated the conferment of the tomos and the enthronement of the new head of the OCU, Metropolitan Epiphaniy (Dumenko). During his speech announcing the Greek Catholic liturgy, Major Archbishop Shevchuk referred to an alleged approval of the responsible authority. However, his statement was fiercely attacked by the 'Honorary Patriarch' of the OCU, Philaret, as being inadmissible. Consequently, the Synod of Bishops of the OCU requested the head of the UGCC to renounce the liturgy for the sake of religious peace. Eventually, President Poroshenko, who saw his election campaign being undermined and feared a loss of votes from the Orthodox or Greek Catholic electorate, joined the dispute. In an attempt to settle the conflict, he invited both church leaders to enter into dialogue. Thereafter, the ministry responsible issued a statement that all religious services must be suspended due to restoration work in the church. These events suggest that, within the next few years, Ukrainian ecumenism is likely to depend on further political and internal church developments, and on how the churches position themselves towards the state, civil society, and other denominations.

32 Stavlennia ukraïntsiv do stvorennia Iedynoï Pomisnoï Tserkvy, Rating Group Ukraine, 17 April 2018, http://ratinggroup.ua/research/ukraine/6541e0064f0288673205fbd06795b94c. html.

${ }^{33}$ Nasha Sviata Sofiia. Poslannia Hlavy UHKTs z nahody stolittia vidnovlennia sobornosti ukraïnskoho narodu ta 1oho derzhavy, Information Resource of the Ukrainian Greek Catholic Church, 24 January 2019, http://news.ugcc.ua/documents/nasha_svyata_sof\%D0\%86ya poslannya_blazhenn\%D1\%96shogo_svyatoslava_z_nagodi_stol\%D1\%96ttya_v\%D1\%96 novlennya_sobornost\%D1\%96_ukrainskogo_narodu_ta_yogo_derzhavi_85063.html. 
At the level of international ecumenical relations, the Moscow Patriarchate withdrew from all commissions chaired by representatives of the Ecumenical Patriarchate. In an audience with Pope Francis, Metropolitan Hilarion stated on 19 October 2018 that, because of tensions with the Patriarchate of Constantinople, the ROC had been forced to suspend its collaboration in the mixed Roman Catholic/Orthodox Commission for theological dialogue. ${ }^{34}$ The internal Orthodox dispute significantly complicates the relationship between the Orthodox and Protestant churches and with the Holy See. In the interests of the Vatican, it will continue to be important to maintain relations with the two Orthodox parties to the conflict, even if it means having to meet separately with the Patriarchate of Constantinople and the Patriarchate of Moscow. This process will require the use of all possible diplomatic skills, to ensure that neither side feels bypassed.

\section{Political Consequences}

In a televised interview, Metropolitan Hilarion asserted on 15 September 2018 that it is quite clear that the actions of the Patriarchate of Constantinople are in the hands of the American government'. ${ }^{35}$ Likewise, albeit slightly less outspokenly, the Declaration of the Holy Synod of the ROC of 15 October 2018 stated that the decisions of Constantinople regarding the issue of Ukrainian Orthodoxy were politically motivated. ${ }^{36}$ In fact, several US government agencies had expressed their positive views on the Ukrainians' aspirations to have an independent church. For now, we can only speculate about the possible influence of American government circles, although this is something the Russian side seems to be certain of, as asserted both by Putin (at his annual press conference in December 2018, for instance) and Foreign Minister Sergei Lavrov. Both have accused the Americans of influencing both Kiev and Phanar. ${ }^{37}$ The circumstances surrounding the conflict between Moscow and Constantinople, however, leave no doubt that it not only has a religious dimension, but clearly also a historically rooted political one. At the same time, both dimensions are shaped and fed by the current political situation. Since the beginning of the conflict between Ukraine and Russia in 2014, polit-

${ }^{34}$ Cf. the website of the Russian Orthodox Church, Predsedatel' OBTsS vstretilsia s Papor Rimskim Frantsiskom, 19 October 2018, http://www.patriarchia.ru/db/text/5287375.html; Heller, ‘Wenn ein Glied leidet, ...', 144-150.

${ }_{35}$ Zwahlen, Ukrainischer Kirchenstreit droht zu eskalieren, 4.

${ }^{36}$ The Russian Orthodox Church, Statement by the Holy Synod of the Russian Orthodox Church.

${ }^{37}$ Alexander Ponomariov, Ukrainian Church Autocephaly. The Redrawing of the Religious Borders and Political Identities in the Conflict between Ukraine and Russia, Russian Analytical Digest 231 (2019) 2-9, 2. 
ical leaders from both countries have used various means to underpin their own positions or to achieve strategic success. The churches are given a special role through both Russia's attempt to influence Ukraine as well as the Ukrainian government's efforts to block this. The reason for this is the complicated history of the Ukrainian state, discrepant historical narrative, and politics of memory in Ukraine and Russia.

\section{'The Rus is Our Common Heritage'}

The Russian historical narrative emphasizes the fact that the history of Russia begins in Kiev and that there are almost no differences between Russians and Ukrainians. The substantiation of this view requires an ideological basis and the identification of a fixed point in the past. Such a point can be found in the Orthodox religion in the form of the baptism of Rus' (988), seen as a unifying bond holding together Russians, Ukrainians, and Belorusians ever since. ${ }^{38}$ The city of Kiev plays a central role in this concept. In unison with the current policy of Russia towards Ukraine, on 21 January 2019, Patriarch Cyril emphasized in a speech during a meeting with representatives of the local Orthodox churches in Moscow:

'Ukraine is not a periphery of our church. We call Kiev "the mother of Russian cities", because for us Kiev is what Jerusalem is to many others. Russian Orthodoxy began there and under no circumstances can we renounce this historical and spiritual connection. The unity of our local church rests upon this spiritual connection. ${ }^{39}$

In its policy towards Ukraine, the Russian state, especially in recent years, has employed a similar rhetoric in regard to the unifying role of the Orthodox faith in the history of the Russians and Ukrainians in order to underpin its claims to supremacy in Eastern Europe. A classic example of this is Russian president Vladimir Putin's address on the Crimean annexation of 18 March 2014, which, once again, makes it clear that the baptism of the Kievan Rus' is indispensable to the origin myth of today's Russian state:

\footnotetext{
${ }^{38}$ On contemporary abuse of the historical myth of the unifying bond of the Baptism of Rus cf. Timothy Snyder, Der Weg in die Unfreiheit. Russland. Europa. Amerika, Munich 2018, 71-74.

${ }^{39}$ The Russian Orthodox Church, Department for External Church Relations, Slovo Sviateǐshego Patriarkha Kirilla na vstreche s delegatsiiami Pomesnykh Pravoslavnykh Tserkvel̆, 31 January 2019, https://mospat.ru/ru/2019/01/31/news169851/. On 19 April 2014, at Easter, he had prayed for the 'People of Russia living in Ukraine', and, in the presence of Putin and Medvedev, emphasized that God should prevent the intentions of those who 'want to annihilate the Holy Rus', cf. V preddverii pashi svjiatejshij patriarh Kirill sovershil molitvu ob Ukraine, Orthodox Christianity, 14 April 2014, http://www.pravoslavie.ru/ news/print70106.htm.
} 
'Literally everything in Crimea is permeated by our common history, our common pride. Here lies the ancient Chersonese, where the holy Prince Vladimir was baptized. The spiritual exploit, the adoption of the Orthodox faith, has laid the common cultural, moral, and civilizing foundation that unites the peoples of Russia, Ukraine and Belarus [...]. Kiev is the mother of Russian cities. The old Rus is our common origin-we belong together.' ${ }^{40}$

Historical arguments are not the only ones used, however. For the current Russian government, the ROC remains an important tool in the pursuit of foreign policy goals. ${ }^{41}$ To illustrate this, the Putin-based ideological project can be described as the 'Russian world' (Russ. Русский минp). ${ }^{42}$ The idea of the 'Russian world' emerged in the 1990s and was initially thought of as a kind of network of Russian-speaking and Russian-thinking communities in the post-Soviet realm, with no obvious political dimension. However, the original project has gained great political significance in recent years, or rather, it has been propagated, in modified form, to achieve political goals. The current interpretation of the term 'Russian world' refers to a kind of cultural realm or Great Russian civilization that includes Russian language, literature, and Orthodox faith and is not limited territorially to today's Russia. The proponents of the 'Russian world' firmly believe that Ukraine is a part of the concept. The ROC plays a central role in this project due to the unifying influence of the Orthodox faith, especially since a good number of Orthodox parishes, along with their corresponding network of Metropolitan or Diocesan structures, are located in those countries which, according to the concept, belong to the 'Russian world'.

${ }^{40}$ Olga Radetzkaja / Volker Weichsel, Rede des russischen Präsidenten Vladimir Putin am 18. März 2014 im Kreml vor den Abgeordneten der Staatsduma, den Mitgliedern des Föderationsrats, den Leitern der Regionalverwaltungen und Vertretern der Zivilgesellschaft, Osteuropa 64, no. 5-6 (2014), 87-99, 87, 96, https://www.jstor.org/stable/44937262. Cf. also Alexander Ponomariov, The Visible Religion. The Russian Orthodox Church and her Relations with State und Society in Post-Soviet Canon Law, 1992-2015, Frankfurt/M. 2017, 109110; Frank Golczewski, Unterschiedliche Geschichtsnarrative zur Ukraine im Kontext der aktuellen Krise, in: Heinz-Gerhard Justenhoven, ed, Kampf um die Ukraine. Ringen um Selbstbestimmung und geopolitische Interessen, Baden-Baden 2018, 35-59, 47-50.

${ }^{41}$ Michael Kemper, Streit um die Orthodoxie in der Ukraine. Die Risiken der kirchenpolitischen Eskalation, Osteuropa 68, no. 8-9 (2018), 143-154.

${ }^{42}$ Thomas Bremer, Diffuses Konzept. Die Russische Orthodoxe Kirche und die 'Russische Welt', in: Osteuropa 66, no. 3 (2016), 3-18; Cyril Hovorun, Interpreting the 'Russian World', in: Krawchuk/Bremer, eds, Churches in the Ukrainian Crisis, 163-171; Oleksandr Zabirko, Russkij Mir und Novorossija. Theologische und nationalistische Konzepte russischer (Außen-)Politik, in: Justenhoven, ed, Kampf um die Ukraine, 63-77; Andriy Mykhaleyko, Gott auf dem Majdan. Die Rolle der Kirchen in der Ukraine-Krise, ContaCOr 17 (2015), 78-84; Ponomariov, The Visible Religion, 109-110. 
With that in mind, the Russian president, on several occasions, made it clear that Russia would not merely impassively sit back and observe the current church and political developments in Ukraine. At the festivities for Patriarch Kirill's anniversary on 31 January 2019, Putin emphasized the principle of non-interference of the state in church affairs, but acknowledged, with respect to Ukraine, that the Russian state reserves the right to react whenever human rights, including the freedom of religious belief, are abused. He was, undoubtedly, referring to the situation of the UOC MP, which, after the creation of the OCU, had fallen into disfavour with Poroshenko's government. In the same speech, Putin accused the initiators of the new ecclesiastical project of 'gross' interference in ecclesiastical affairs and compared them with the Bolshevik atheists, who persecuted believers and priests in the 20th century. ${ }^{43}$

\section{'A Church Without Putin'}

On the Ukrainian side too, the church issue is being mobilized for political purposes. The Ukrainian state's interest in the question of the church and its involvement in autocephalic aspirations can be looked at from both a longterm and a short-term perspective. In the long term, ecclesiastical autocephaly could be classified as a means of further separating Ukraine from Russia and as part of the political strategy for maintaining integrity, building a common identity and strengthening national unity.

The same goals were pursued in the quest for autocephaly 100 years ago. At that time, too, the protagonists of the independent church were concerned with the independence of the Ukrainian nation as well as political independence. After a slight delay in recognizing the importance of religion for state policy, the ephemeral Ukrainian state government of 1918 saw the independence of the church from Moscow as more of a calculated political move than one motivated by religious conviction. This was a logical consequence of the development and in fact a political necessity for the internal and external stabilization of the state. In an address to the All-Ukrainian Church Sobor in Kiev in November 1918, Oleksander Lototskyj, Minister of Religious Affairs, stated that:

'The Ukrainian state government's basic position is that in an independent state, there must be an independent church. The interests of the state and the interests of the church both equally demand this. No government aware of its responsibilities can accept a situation where the centre of church authority resides in another state. $^{44}$

\footnotetext{
${ }^{43}$ Putin sravnil initsiatorov novogo tserkovnogo proekta na Ukraine s bezbozhnikami XX veka, tass, 31 January 2019, https://tass.ru/politika/6064331.

${ }^{44}$ Ricarda Vulpius, Der Kirchenkampf in der Ukraine als Beispiel für Sakralisierung der Nation und Nationalisierung der Religion, 1917-1921, in: Martin Schulze Wessel, ed,
} 
Just as in the past, the then President of Ukraine, Petro Poroshenko, interpreted the dependence of a part of Ukrainian Orthodoxy on the Moscow Patriarchate as one of Russia's last political mechanisms to influence Ukraine, and as such something that should be stopped:

'If the central government of a church is located in a foreign country and if this country is an aggressor, what kind of citizen will they educate? Certainly not a citizen of Ukraine. The Kremlin in no way hides the fact that it considers the ROC to be one of the main instruments of influence over Ukraine. ${ }^{\prime 45}$

The head of the OCU, convinced that the ROC is Putin's last 'bulwark' in Ukraine, agrees with the president. ${ }^{46}$

While in 1919, the Minister of Religious Affairs, Oleksander Lototskyj, had been unsuccessful in his attempt to negotiate with the Ecumenical Patriarch in Constantinople on the conferment of the autocephaly status, ${ }^{47}$ the overall conditions were more favourable in 2018-2019. A century ago none of the Orthodox bishops had agreed to consecrate and establish a legitimate hierarchy for a Ukrainian autocephalic church, as opposed to the then Orthodox Church in Georgia, which had declared itself autocephalic in 1917 with the support of several bishops. A century later, in 2018, the new church in Ukraine was supported by over 60 bishops and had also come to be supported by society. In his highly emotional speech after the Unification Council on 15 December 2018, which was characterized by a strong anti-Russian rhetoric, Poroshenko summarized the importance of autocephaly. He thanked the 'Mother Church' of Constantinople for healing the wounds inflicted on Ukrainian Orthodoxy by centuries of 'Moscow rule'. These words were reminiscent of the arguments put forward by the 1920s proponents of the independent church. While, to this day, the Patriarchate of Moscow considers 1686 the year of the 'reunification of the Russian Church', ${ }^{48}$ in Ukraine, already in 1918, the past 200 years were

\footnotetext{
Nationalisierung der Religion und Sakralisierung der Nation im östlichen Europa, Stuttgart 2006, 101-118, 107-108; Cf. also Bohdan R. Bociurkiw, The Issues of Ukrainization and Autocephaly of the Orthodox Church in Ukrainian-Russian Relations, 1917-1921, in: Peter J. Potichnyj et al., eds, Ukraine and Russia in Their Historical Encounter, Edmonton 1992, 245-273, 248-250.

${ }^{45}$ Address by President Poroshenko after the Unification Council, Poroshenko pryvitav hromadian Ukraïny zi stvorenniam Pomisnoï tserkvy, ukrinform, 15 December 2018, https:// www.ukrinform.ua/rubric-society/2601728-porosenko-privitav-gromadan-ukraini-zistvorennam-pomisnoi-cerkvi.html.

${ }^{46}$ Epifanii otsinyv vplyv RPTs v Ukraïni, Radio Svoboda, 2 February 2019, https://www. radiosvoboda.org/a/news-epifanij-pcu-rpc-ukrajina-vplyv/29747849.html.

47 Vulpius, Der Kirchenkampf in der Ukraine, 108.

${ }^{48}$ The Russian Orthodox Church, Statement by the Holy Synod of the Russian Orthodox Church.
} 
defined as a period of unnatural dependence on Moscow and of the Russification of ecclesiastical life. ${ }^{49}$

In December 2018, President Poroshenko described the OCU as a 'church without Putin', without Patriarch Cyril, and without prayers for the Russian government and the Russian army:

'Like no others we know: wherever the Russian thurible sways today, multiple Russian rocket launchers will be used tomorrow. At first, Patriarch Cyril travelled to Ukraine spreading the propaganda of the "Russian world" and the joint baptismal font, and now Russian tanks have rolled in there! It is obvious that the question of autocephaly goes far beyond the ecclesiastical context. This is a question of our national security. This is a question of our statehood. This is a question of world politics [...]. No patriot doubts how important it is to have an independent Orthodox Church in the independent Ukrainian state. Such a church is a guarantee of our sovereignty [...] Autocephaly is part of our pro-European and pro-Ukrainian strategy, which we have consistently implemented for almost five years. All this is the basis of our own development, the development of the state of Ukraine and the development of our Ukrainian nation..$^{50}$

The role of former president Poroshenko in the current aspirations as well as his personal interest in this project were unmistakable. In the short term, his efforts to attain autocephaly were an important component of the presidential election campaign of 2019. Considering the difficult economic circumstances, the lack of progress in resolving the conflict in eastern Ukraine, and the corruption scandals that were happening around him, the then president had to demonstrate some political and strategic successes in order to be reelected. The establishment of an Orthodox autocephalous church in Ukraine, independent from Moscow, was, undoubtedly, also considered a political success on the part of President Poroshenko. Thus, he skilfully put himself in the foreground of all the major events concerning the conferment of autocephaly and the allocation of the tomos. On 15 December 2018, Poroshenko held a seat on the Board of the Unification Council and, following the election of the new head of the OCU, he was permitted to announce his name in a speech at the end of every meeting of the Board. He travelled to Istanbul for the signing of the tomos by the Ecumenical Patriarch and is listed by name in the document of the tomos.

Poroshenko's government and election campaign team also used the magnitude of the event for the purpose of mass mobilization. What were dubbed the 'tomos tours' through Ukraine were the cause of great outrage and criticism.

\footnotetext{
${ }^{49}$ Vulpius, Der Kirchenkampf in der Ukraine, 114-115.

${ }^{50}$ Poroshenko pryvitav hromadian Ukraïny zi stvorenniam Pomisnoï tserkvy, ukrinform, 15 December 2018, https://www.ukrinform.ua/rubric-society/2601728-porosenko-privitavgromadan-ukraini-zi-stvorennam-pomisnoi-cerkvi.html.
} 
These were visits to the Ukrainian regions, where, in an ecclesiastical setting, the tomos document was solemnly presented to the public. During these visits, the president continuously drew attention to himself and the new church gave him (or, most likely, had to give him) a suitable setting. His competitors for the presidency accused him of exploiting the religious issue during the election campaign.

The euphoria surrounding the tomos has barely taken into account the fact that Ukraine is a multiconfessional or rather a multireligious country in which church and state are separated under the constitution. Accordingly, all churches and religious communities are to be treated equally by the state. In reference to this, the president put pressure on the UOC MP in particular. On 20 December 2018, the Ukrainian parliament passed a law on the renaming of religious organizations, which mandated that the UOC MP be, de facto, renamed to make the affiliation with the Patriarchate of Moscow evident. ${ }^{51}$ Although the UOC MP is referred to by radical forces as the fifth column of Moscow, it must not be forgotten that after the Unification Council, in terms of its number of parishes, this church is and will remain the largest Orthodox church, with a much better developed infrastructure than all the other Orthodox communities. It is also made up of millions of dedicated Ukrainians and enjoys strong support from opposition politicians, especially in the eastern regions of Ukraine. Ignoring it or branding its members as Russian agents is not a sensible or sustainable ecclesiastical policy.

The presidential elections held in April 2019 provided another important conclusion for the future state ecclesiastical policy. According to the official outcome of the second round on 21 April 2019, Poroshenko received only 24.45 percent of the votes in comparison to his opponent, Volodymyr Zelenskyj, who won three times as many votes (73.22 percent). Thus, despite all efforts to play the religious card, Poroshenko ultimately failed to capitalize on it. It appears that the Ukrainian population are no longer as engrossed in religious issues, at least not to the extent that including religion in campaign propaganda would significantly affect the election outcome.

\section{Conclusion}

The primary goal of forming an independent church in Ukraine was to overcome the nearly 30-year division within Ukrainian Orthodoxy. After the Unification Council of 15 December 2018 and after the conferment of the tomos to the OCU, an entirely new ecclesiastical constellation arose in Ukraine. The merger of the UOC KP and the UAOC reduced the number of Ortho-

${ }^{51}$ Buchholz, Zwischen Spaltungen und Einheitsbestrebungen, 103. 
dox churches in Ukraine from three to two. However, one can only consider this undertaking a partial success. Due to the events in Ukraine, a division of another kind emerged at the same time, one which far exceeds the magnitude of the Ukrainian division. From the point of view of the Patriarchate of Constantinople, the non-canonical status of a part of Ukrainian Orthodoxy, which had existed until that point, was corrected. Patriarch Bartholomew's decision to confer autocephaly caused the derogation of the Eucharistic Communion between the Moscow Patriarchate and Constantinople and a new and momentous schism in World Orthodoxy. While Constantinople adopted the OCU, which it itself had founded, as the 15th church in the Orthodox Diptychs, Moscow not only refused to recognize it, but temporarily removed the name of the Patriarch of Constantinople from the list of liturgical commemorations.

It remains to be seen whether the founding of the new church in Ukraine can significantly change the balance of power within World Orthodoxy. On 31 January 2019, Patriarch Cyril estimated the number of Orthodox churches at $38,649.52$ Considering that nearly a third of these communities are located in Ukraine, the Patriarchate of Moscow would have reason to fear being deprived of its uncontested supremacy through this loss. The relinquishment of Ukraine is therefore not an option.

Moreover, after the conferment of autocephaly, the inter-church situation in Ukraine is far from harmonious. Not only is there potential for conflict in the relationship between the OCU and the UOC MP and between the OCU and the UGCC, but such potential even exists within the OCU itself. In May 2019, there was a public dispute over the leadership roles in the OCU. Even though the new head of the OCU, Metropolitan Epiphany, was elected 'Honorary Patriarch' at the council in December 2018, Philaret has claimed this office and title for himself. In a public statement on 14 May, he alleged that he had been betrayed by both Poroshenko and Metropolitan Epiphany. ${ }^{53}$ If he is to be believed, he had received a verbal promise during the Council in December 2018 that, despite the election of Metropolitan Epiphany, he would lead the OCU and the Metropolitan would be merely an outward representative in the Orthodox world. He would continue to maintain his position as Patriarch of the UOC KP, which he is convinced never ceased to exist. He purports that his consent to the dissolution of the Unification Council on account of the merger of the UOC KP and UAOC in the OCU, was only given due to the sit-

${ }^{52}$ Cf. the website of the Russian Orthodox Church, Systuplenie Sviatershego Patriarkha Kirilla na torzhestvennom akte, posviashchennom 10-letiiu Pomesnogo Sobora i intronozatsii Iego Sviatershestva, 31 January 2019, http://www.patriarchia.ru/db/text/5364415. html.

${ }^{53}$ Vidmova vid statusu Patriarkhatu bula chysto sytuatyvnoiu, pochesnyı̌ Patriarkh Filaret vystupyv iz zaiavoiu, Religious Information Service of Ukraine, 15 May 2019, https:// risu.org.ua/ua/index/all_news/orthodox/ocu/75797/. 
uation at the time. This conflict, which in itself reflects the internal tensions between the old and the new elite over leadership and claims to power, could, in the near future, not only harm the reputation of the OCU in the Orthodox world and its recognition by World Orthodoxy, but also seriously endanger its unity in Ukraine and the unification processes initiated with the other Orthodox branches in Ukraine.

The proponents of the independent church desired and expected that more bishops of the UOC MP would join the OCU than actually did. Only two out of more than 80 took this step. Thus, two Orthodox churches now stand opposite each other: the UOC MP with about 12,000 registered churches and the OCU with about 7,000 churches. The communities of the latter are made up of the merger of the UOC KP and UAOC as well as the approximately 500 UOC MP communities which, in one way or the other, changed over to the OCU, or rather expressed their willingness to take this step. However, it should be noted that not all of these 500 communities are yet properly registered as parishes of the OCU, due to the fact that the re-registration is a lengthy process and requires those involved to complete several bureaucratic procedures. In addition to this, it seems that the progress of the communal change to the OCU lost its momentum following the presidential elections of 2019. It can therefore be presumed that that momentum was, at least in part, related to the elections and to the political cycle of the last five years. Had Poroshenko been re-elected, it might possibly have continued. With the victory of Volodymyr Zelenskyj, the leadership of the UOC MP has been expecting Ukraine's church policy to be subject to revision. This expectation has already been voiced several times in Moscow. In an interview on 18 April 2019, Metropolitan Hilarion expressed the hope that the new president would abandon the policy of 'persecution' of the UOC MP and correct his predecessor's mistakes in church issues. ${ }^{54}$

Another example of how the political constellation influences the church situation are the results of surveys regarding religious denomination. According to these surveys, the OCU has more followers, in terms of percentage, than its counterpart. A survey carried out between 16 and 29 January 2019 showed that 43.9 percent of respondents claimed to feel more affiliated with the OCU and only 15.2 percent felt an affiliation with the UOC MP, even though the UOC MP has nearly twice as many communities. Interestingly, the number of people calling themselves 'simply Orthodox' is 38.4 percent. ${ }^{55}$ This dis-

${ }^{54}$ Cf. the website of the Union of Orthodox Journalists, Ierarkh RPTs. Verim, chto Zelenskiĭ prekratit presledovanie veruiushchikh UPTs, 28 April 2019, https://spzh.news/ru/ news/61783-ijerarkh-rpc-verim-chto-zelenskij-prekratit-presledovanije-verujushhih-upc.

${ }_{55}$ Pres-Reliz za rezul'tatamy soziolohichnoho doslidzhennia 'Ukraïna naperedodni prezydents'kykh vyboriv 2019', SOCIS - Centr social'nih ta marketingovih doslidzhen', 1 February 2019, http://socis.kiev.ua/ua/2019-01/?fbclid=IwAR1zWSwvp0rGIKIPIZSWAZSfuQsBBw24CeoiEAyT7vaIQ2eHPgnlOvJ9eI. 
crepancy in numbers can be explained by the fact that believers who claim to be Orthodox, regardless of their actual confessional affiliation in the current political climate, are unlikely to want to be part of a church whose centre is in Moscow.

Regardless of how the ecclesiastical situation in Ukraine and in World Orthodoxy now develops, it is obvious that the churches in both Russia and Ukraine need to liberate themselves from political influences and political instrumentalization. The abuse of religious issues reached a new peak in 2018. Political actors in both countries have not been hesitant in their attempts to play the ecclesial card for their own benefit. It is, therefore, up to the churches to not allow themselves to be instrumentalized, so as not to lose face in civil society. In the case of Ukraine, ecclesial diversity still seems to offer an opportunity to balance religious power structures. This diversity relativizes the dominance of a single church and could discourage churches from entering into coalitions with the state, which in the long run could prove to be disadvantageous.

In fact, in order for Ukraine to achieve harmonious inter-church coexistence and a constructive relationship between state and church, it could fall back on previously existing and well-reinforced structures, such as the Ukrainian Council of Churches and Religious Organizations, established in $1996 .{ }^{56}$ One of the main tasks of the organization is the promotion of inter-faith dialogue and cooperation with the state as a consultative body on the development of legal norms in church-state relations. The work of the All-Ukrainian Council has been based on the principle of equal rights and respect for individual ecclesiastical or religious traditions. Currently, the council is made up of 18 churches and religious organizations. In total, more than 95 percent of the religious realm, the most important Christian denominations and religions in Ukraine, including Orthodox, Greek Catholic, Roman Catholic, Protestant, Jewish, and Muslim, is covered. The effectiveness of the Council was particularly evident during the Maidan protests in late 2013 early $2014 .{ }^{57}$ Perhaps this is the very institution to ensure a balanced religious situation in Ukraine in the future.

Translated from the German by Rebecca D. Parker

\section{CORRESPONDING AUTHOR}

Andriy Mykhaleyko Ingolstädter Str. 3, 85111 Adelschlag/Ochsenfeld, Germany.

E-mail: mykhaleyko@ucu.edu.ua

\footnotetext{
${ }^{56}$ Cf. Andrii Krawchuk, Constructing Interreligious Consensus in the Post-Soviet Space. The Ukrainian Council of Churches and Religious Organizations, in: Krawchuk/ Bremer, eds, Eastern Orthodox Encounters of Identity and Otherness, 273-300.

${ }^{57}$ Mykhaleyko, Gott auf dem Majdan, 33-46.
} 